\title{
Agenda setting, agenda blocking and policy silence: why is there no EU policy on prostitution?
}

\author{
Gill Allwood, Nottingham Trent University, UK \\ Women's Studies International Forum, accepted for publication 8 June 2018
}

The EU has expanded its policy remit into all kinds of areas, and has made a clear commitment to gender equality. However, issues such as prostitution, abortion and same-sex families, which many would argue are closely linked to gender equality, have remained absent from the EU policy agenda. This article takes the case of prostitution, and asks how we explain the EU's policy silence on this issue, despite its clear action on the closely related issue of trafficking in human beings (the 2011 Anti-Trafficking Directive (European Parliament \& The Council, 2011); the appointment of an Anti-Trafficking Coordinator; and the Strategy towards the Eradication of Trafficking in Human Beings (2012-2016) (European Commission, 2012)). Using a combination of process tracing and document analysis, it examines how prostitution has been kept off the policy agenda; how it has been framed as a policy issue; which actors have been able to define the issue, and which have been excluded. The article contributes to a broader understanding of why some issues become defined as problems requiring public policy responses and others do not; how they appear on, or are excluded from, the policy agenda at the member state and EU level; and how issues, frames and proposals are ignored or actively silenced within policymaking structures and processes.

\section{Introduction}

The European Union (EU) has expanded its remit to such an extent that almost all areas of public policy are affected in some way by EU decision making (Buonanno \& Nugent, 2013, p. 6; Nugent, 2017, p. 165). Many new issues have been brought onto the EU agenda by actors successfully framing them in such a way that they appear connected to the EU's central concerns, in particular the single market (Princen, 2011b, p. 936). However, in the case of issues such as prostitution, abortion and same-sex families, this strategy has failed. Actors seeking to place prostitution on the EU agenda by framing it as an economic activity have been met with the argument that it falls outside the competence of the EU. This article asks whether the competence argument provides a satisfactory explanation for the EU's policy silence on prostitution. It does not advocate EU action on prostitution, but tries to solve the puzzle of its exclusion from an expanding and almost all-encompassing policy agenda.

The aim of the article is to establish why some issues fail to gain traction on the EU policy agenda. It takes the case of prostitution and asks who has tried to place prostitution on the agenda or keep it off the agenda; how it has been framed, and how these frames have been rebutted or ignored or twisted; what are the institutional processes which have facilitated/blocked access; and what has been the impact of the wider policy environment/political context. These questions are answered through an analysis of documents produced by the EU and civil society organisations. The analysis finds that silencing takes place through the use of the competence argument; framing plays an important part in silencing and in attempts to break the silence; there are differences between the EU institutions in the extent to which prostitution is present on, or absent from, the agenda; and sex workers' rights advocates and their discourse are excluded from decision making and debates. The Commission and the Council's silence on the issue effectively excludes it from the policy agenda. Sex workers' rights advocates are excluded from decision-making and debates, and their discourse is silenced. 
The article challenges the argument that prostitution is absent from the EU because it falls outside its competence. It argues that competence is not fixed, but is the product of interpretation. Instead of explaining prostitution's absence from the EU agenda, competence is used to silence attempts to raise the issue. This shows that policy silence is not a passive state, but the result of active and repeated acts of silencing. The article shows how some problems, issues and frames are ignored, excluded or refused entry, actively or passively, knowingly or not. In so doing, it contributes to the scholarly literature on agenda setting and to the smaller literature on agenda blocking and policy silence. This is important because most agenda setting studies focus on issues which have achieved agenda status, ignoring those which have not.

The article is structured in the following way. First, it sets out the two dominant explanations for prostitution's absence from the EU agenda, which are suggested by the existing literature. These are that the issue is too controversial and that it lies outside the EU's competence. It then turns to the agenda setting literature which asks how and why some problems become defined as issues worthy of policymakers' attention and how and why some of these issues become the subject of decision making. Agenda setting scholars focus on how actors, frames, institutions and policy environment come together to open up opportunities for new issues to arrive on the agenda. Rarer studies of issues which fail to gain agenda status contribute to our understanding of agenda blocking and policy silence. Drawing on the conceptual tools developed in the existing literature, this article builds a framework to analyse documents produced by the EU and by civil society organisations. The findings of the analysis are presented in the empirical section, and this is followed by the conclusion.

\section{Controversy and Competence}

Some authors argue that issues that are too controversial or sensitive are not brought to the EU agenda, because of its consensus-seeking policymaking processes. Princen (2011a, p. 940), for example, writes: 'the high thresholds needed for decision- making in the EU (many institutions, qualified majority voting or unanimity in the Council) make it risky to stir up too much controversy. Controversy is likely to mobilize opponents, who in the EU system can relatively easily block policy initiatives'. Catherine Hoskyns (1996, p. 168), in her seminal work on women, law and politics in the European Union, asks why the EU had, by 1996 when her book was published, developed a women's policy, but not a common immigration and a race relations/anti-racism policy. She argues that immigration and race relations were too controversial, generating conflict between the Commission and the member states and within the European Parliament. Member state governments blocked any expansion of the Community's remit in areas that were sensitive, limiting them, at most, to intergovernmental coordination. More recently, Kronsell (Kronsell, 2012, p. 31) has argued that the Commission's 'consensus-seeking character means that activist organisations presenting controversial or more conflicting positions do not stand much of a chance of having their voices heard.'

Certainly in the case of prostitution, there is evidence to suggest that member states disagree strongly. In 1999, Sweden became the first European country to criminalise the purchase of sexual services and, in the same year, the Netherlands legalised all aspects of the sex industry, including pimping and brothel owning (Outshoorn, 2004, p. 6). In just one year, prostitution policy in EU member states became starkly and visibly polarised. However, the exclusion of controversial issues from the EU policy agenda is not absolute, and policies unpopular in some member states have been successfully introduced. Examples of controversial legislation that has been passed include environmental policies, many of which are in the form of directives 
and many of which are met with very different views from member states (Nugent, 2017, p. 198). Sustainable development, climate change and energy security are all persistent policy problems that can pose serious challenges to the EU governance system (Candel, Breeman, \& Termeer, 2016, pp. 525-6), but they nevertheless remain on the EU policy agenda. The controversial nature of the issue cannot on its own be taken as a satisfactory explanation for policy silence on prostitution, although it could be a contributory factor. The member states are divided and, for those with legalised sex industries, economic interests are at stake (Elman, 2007). It is certainly the case that less divisive issues have been separated from the issue of prostitution itself and legislated upon quickly and decisively. Such is the case for trafficking in human beings, and child prostitution and pornography.

Asserting that the EU cannot act on prostitution because it falls outside its area of competence is the most frequent reason given for prostitution's exclusion from the EU agenda, as will be demonstrated later in this article. Joyce Outshoorn $(2018$, p. 1), for example, states that it is unsurprising that the EU has policy on trafficking in human beings but not on prostitution, because the transnational phenomenon of trafficking in human beings falls within the competences of the EU, whereas prostitution remains an issue for member states.

The EU's competence to act in any policy area is determined by the Treaties, which set out the competence of each institution in relation to the others and the competence of the EU in relation to the member states (Nugent, 2017, pp. 105-6). However, the EU's competence is not fixed. It has expanded with successive treaties to encompass a single market and everything associated with the free movement of people, goods, services and capital. New issues have been brought to the agenda, often by successfully framing them in such a way that they appear inextricably linked to the concerns of the EU and primarily to the single market (Princen, 2011 b, p. 936). Is it possible to continue arguing that prostitution is inherently outside the EU's competence, when there are so many ways that it could be linked to EU concerns?

\section{EU agenda setting}

A large literature contributes to our understanding of how new issues arrive on the EU policy agenda. A distinction is made between the governmental agenda - all issues that are being discussed without any concrete proposals for decision making - and the decision agenda those issues on which active decisions are being made (Princen, 2011a, pp. 108-9, 2012, p. 35). It is more difficult for actors to influence the EU's decision agenda than its governmental agenda (Buonanno \& Nugent, 2013, p. 103; Princen, 2012, p. 36). For the purposes of this article, an issue is deemed to be 'on the EU agenda' when it receives serious attention from the agenda setting and decision making institutions (the Commission, the Council and the European Parliament) (Princen, 2012, p. 29). It is possible for one of the institutions, for example, the European Parliament, to debate the issue and even to pass a Resolution on it without it being on the broader EU agenda.

Agenda setting involves the interaction of some or all of the following: actors, frames, institutions and political environment. Actors include institutional insiders, as well as social movements and advocacy coalition networks. They attempt to push their issue onto the EU agenda by targeting receptive individuals and institutions; mobilising support; and framing the issue in such a way that it resonates with EU priorities and concerns (Princen, 2012, p. 29). Framing means selecting for attention a few salient features and relations and organising them in a coherent manner to describe what is wrong with the current situation and what should be done about it (Schön \& Rein, 1994, p. 26). Feminist agenda setting scholars have been 
particularly interested in activism and mobilisation as ways of bringing new issues onto the political agenda (Joachim, 2007; Kenney, 2003; Montoya, 2013; Randall, 1987; Weldon, 2002). They have shown, for example, that trafficking in human beings was brought onto the EU agenda by a coalition of actors, mobilising frames which brought the issue clearly into the remit of the EU (Askola, 2007; Birgit Locher, 2007).

The institutional framework influences which issues arrive on the agenda and which are blocked (Princen, 2007, p. 22). The EU has a particularly complex institutional make-up, producing both opportunities and constraints. The number and variety of institutions means that policy advocates can normally find individuals or committees or bodies willing to pay attention to their attempts to place the issue on the agenda (Princen, 2011b). However, there are numerous veto points and it is difficult to move from discussion to decision (Princen, 2011b). Institutions, in the sense of the formal and informal rules of the game, can shape change or produce resistance (Mergaert \& Lombardo, 2017) and can contribute to certain issues being seen to fall inside or outside the policy remit (Gains \& Lowndes, 2015, p. 5). Feminist scholars have always been interested in exposing the ways in which institutions ignore or exclude certain issues and actors (Lovenduski, 1986), and this has been consolidated in feminist institutionalism (Kenny \& Mackay, 2009; Mackay, 2011; Mackay \& Waylen, 2009; Waylen, 2013).

The political environment can affect which issues stand a chance of receiving serious attention from decision makers (Princen, 2012, p. 31). Heightened security concerns, a period of economic crisis, or a series of unexpected election results will open up opportunities for some issues and shut down opportunities for others. They will also affect how actors frame issues in order to attract the interest of agenda setters and decision makers.

To summarise, issues arrive on the EU agenda when they are pushed by actors, framed in a way that fits with EU priorities and commitments, find a receptive institutional venue, and the external conditions are favourable. The absence of these conditions can contribute a partial explanation for issues failing to gain agenda status. The smaller literature on agenda blocking and policy silence provides further elements.

\section{Agenda blocking and policy silence}

The agenda setting literature seeks to explain why some issues arrive on the policy agenda and how they get there. Most agenda-setting studies start with issues that have successfully arrived on the policy agenda and trace backwards to explain how this happened (Princen, 2016, p. 362). Explanations for the failure of other issues to reach the policy agenda are rarer. Recent feminist scholarship has shown that failure to place an issue on the agenda can be a result of the actors' reduced access to agenda setting processes or reduced influence over the way in which the problem is defined. This makes an important contribution to filling one of the gaps left by the agenda-setting literature, introducing a focus on power within the institutions and between actors, some of whom can be excluded, silenced or ignored. Their capacity to participate and influence can be affected by external events and the broader political environment, opening or closing a window of opportunity for their intervention (Annesley, Engeli, \& Gains, 2015; Gains \& Lowndes, 2015). The excellent secondary literature which traces how trafficking arrived on the EU agenda in the 1990s (Askola, 2007; Birgit Locher, 2007; Outshoorn, 2018) points to the obstacles which prevented its earlier arrival on the agenda and to the actors, frames and political opportunity structures which facilitated its eventual arrival. Locher (Birgit Locher, 2007, p. 154) argues that during the 1970s and 1980s, political opportunity structures were not favourable to trafficking achieving agenda status. The 
European Community presented itself as an economic project, and gender equality was seen only within an economic context. Neither the Council of Ministers nor the Commission reacted to the European Parliament's resolutions on violence against women (1986) or trafficking (1989). The Council continued to approach trafficking in women as an immigration issue (Birgit Locher, 2007, p. 149). Locher argues that 'there was no discursive link between the European institutions that was favourable for negotiating and reframing trafficking in women from an angle outside the narrow illegal immigration frame. In fact, the Council and the European Parliament represented two irreconcilable approaches to trafficking, originating from two completely separated discourses and different institutional cultures, that offered no space for intersections or overlaps' (Birgit Locher, 2007, p. 150). Trafficking was brought onto the EU agenda by femocrats, politicians, academics and NGOs, joined together in a powerful advocacy coalition, and benefiting from windows of opportunity produced by the Dutroux scandals in Belgium, the accession of the Nordic states, and the creation of the Justice and Home Affairs pillar of the European Union to advance their frames (B Locher, 2012, p. 78). Can we draw parallels between trafficking's absence from the EU agenda in the 1970s and 1980 s, and prostitution's absence today?

The mainstream EU agenda setting literature contains only implicit insights into the failure of some issues to acquire agenda status. Princen (2011b, p. 939), for example, suggests that in order to understand why some issues are absent from the policy agenda, it is necessary to invert his typology for understanding agenda setting (Princen, 2011b, p. 939): 'As the opposite of strategies to 'gain attention', actors may try to distract attention by seeking sympathetic venues and framing issues in 'technical' terms so as to depoliticise them. Moreover, actors may undermine (rather than build up) the credibility of EU action by constraining the capacity for action (eg by diverting resources away from some part of the Commission) or creating doubt about the EU's authority in a given field (eg by raising subsidiarity concerns)' (Princen, 2011a, p. 939).

Agenda blocking is a powerful way of preserving the status quo (Princen, 2011b, p. 939). The inability to gain decision-makers' attention is the inability to press for change. Sally Kenney, for example, writes: 'Keeping items off the agenda and blocking is one of the most important powers there is' (Kenney, 2003, p. 187). Nathalie Tocci (2016), policy advisor to the EU's High Representative for Foreign Affairs and Security Policy, Federica Mogherini, states that in order to exclude issues from the agenda, they are just ignored, and ignored some more.

The nature and rules of the policy process mean that some groups are better able to influence policy than others. This is not solely a result of intentional behaviour or unequal resources. As Schattschneider states: "All forms of political organisation have a bias in favour of the exploitation of some kinds of conflict and the suppression of others because organisation is the mobilisation of bias. Some issues are organised into politics while others are organised out' (1960)' (Birkland, 2007, p. 66).

The agenda-setting literature aims to explain how some issues gain traction in the policymaking process and others do not. What it does not do so well is explain why some issues are excluded from the EU policy agenda. This article contributes to this literature by analysing how prostitution is excluded from the EU policy agenda.

\section{Methodology}


Four theoretical explanations for the absence of an issue from the EU's policy agenda are suggested by the existing literature: the EU policy agenda excludes controversial issues; the EU policy agenda is determined by competence; issues only arrive on the agenda when actors, frames, institutions and a favourable political environment coincide; agenda blocking and organisational bias act as powerful obstacles to the arrival of new issues. On the basis of this, I have developed an analytical framework for understanding the failure of attempts to place issues on the EU policy agenda and tested it in the case of prostitution. The following questions are asked:

1. Who has tried to place prostitution on the agenda/keep it off the agenda?

2. How has it been framed, and how have these frames been rebutted/ignored/twisted?

3. What are the institutional processes which have facilitated/blocked access?

4. What has been the impact of the wider policy environment/political context? Is the political context favourable/unfavourable to EU level prostitution debates?

The data consists of EU documents, and documents produced by civil society organisations and the European Women's Lobby. In order to trace the inclusion and exclusion of prostitution from the EU policy agenda, all documents containing the terms 'prostitution' and/or 'sex work' were identified in the EUR-Lex database. EUR-Lex provides access to: the Official Journal of the European Union; EU law (EU treaties, directives, regulations, decisions, consolidated legislation, etc.); preparatory acts (legislative proposals, reports, green and white papers, etc.); EU case-law (judgments, orders, etc.); international agreements; EFTA documents; summaries of EU legislation; and other public documents.

A keyword search of 'prostitution' in EUR-Lex returned 891 documents (1980-2016). A keyword search of 'trafficking in human beings' returned 3854 (both conducted on 25 March 2016). In contrast, a keyword search of 'sex work' returned just nine documents (9 May 2016). All of the documents containing 'prostitution' and/or 'sex work' were retained for analysis with the exception of those which contained only single references to the title of Conventions and protocols such as the "UN Convention on the Rights of the Child and the Optional Protocols thereto, including the fight against child labour, child trafficking and child prostitution', when that was the only reference to prostitution in the document. Similarly, documents were excluded when there was a single mention of prostitution in a list of business activities excluded from a measure under discussion, or a single reference to child prostitution and child pornography as illegal activities. The EU 2011 Anti-Trafficking Directive, the 2012-16 Strategy and the mid-term report on the implementation of the Strategy (2014) make no mention of prostitute(e)(ion) or sex work(er). All documents containing the terms sex work, sex worker, sexual services, excluding the purchase of sexual services from minors, child prostitution and pornography, and sexual services from victims of trafficking in human beings were also retained for analysis. Evidence of silencing was collected by tracing what happens when the issue is raised. How is it dismissed, ignored, or bypassed? Which voices are not present or not heard? Where have NGOs tried to enter the debate and failed, how and where have their voices been excluded?

The next level of analysis investigated how competence arguments were used; how different actors used different frames to include or exclude prostitution; institutional variation; and the absence or marginalisation of sex work discourse. The findings are presented in the next section.

\section{Explaining the Silence}


EU policy documents rarely mention prostitution. When they do, it is often in the context of HIV prevention targeting particular groups including prostitutes (early 1990s), child prostitution and pornography (mid 1990s), and trafficking in human beings for the purpose of the exploitation of prostitution (early 2000s). The analysis produced four key findings:

1. Silencing takes place through the use of the competence argument;

2. Framing plays an important part in silencing and in attempts to break the silence;

3. There are differences between the EU institutions in the extent to which prostitution is present on, or absent from, the agenda and the ways in which it is framed. The Commission and the Council's silence on the issue effectively excludes it from the decision agenda.

4. Sex workers' rights advocates are excluded from decision-making and debates, and their discourse is silenced.

Finding 1 Silencing takes place through the use of the competence argument.

Prostitution is regularly rebuffed as falling outside the competence of the EU. There are many examples of the use of the competence argument to justify prostitution's absence from the EU policy agenda (for example, (Dury, 1989; Tomašić, 2014; van Dijk, 1989; Zuber, Auconie, Honeyball, Kiil-Nielsen, \& Parvanova, 2013). When efforts have been made to bring prostitution onto the EU agenda through questions for written answer to the Commission and the Council, they have received responses stating that the EU had no competence in this area (1980s and 1990s); that the EU had no competence on prostitution, but a commitment to combat trafficking in human beings (2000s); and that the EU had no competence on prostitution but a mandate to address prostitution in so far as it relates to sexual exploitation and trafficking in human beings (2010s).

Sexual exploitation of women and girls does fall within the competence of the EU (Aricle 83 TFEU), but is rarely, if at all, defined. References to sexual exploitation in the documents analysed relate to the sexual exploitation of children and to trafficking for the purposes of sexual exploitation. The 2014 European Parliament Report, authored by Mary Honeyball (Honeyball, 2014) was entitled: 'Report on Prostitution and Sexual Exploitation and its Impact on Gender Equality.' It 'Urges the Commission and the Member States to mobilise the necessary means and tools to fight trafficking and sexual exploitation and to reduce prostitution as breaches of women's fundamental rights - in particular with regard to minors - and gender equality.' In the European Women's Lobby's Brussels Call for a Europe free from prostitution (Lobby, 2013), sexual exploitation and prostitution become synonyms: 'Globally, women constitute $85 \%$ of the victims of trafficking for sexual exploitation (prostitution). Globally, $79 \%$ of reported trafficking in human beings is for sexual exploitation (prostitution). In Europe, $76 \%$ of trafficking in human being is for sexual exploitation (prostitution).' Making the link between sexual exploitation, which does fall within the EU's competence and prostitution, which does not, is a strategy for seeking agenda status, and this strategy depends on framing.

Stating that silencing takes place through the use of the competence argument is not the same as saying that prostitution is absent from the EU's policy agenda because it falls outside the EU's competence. Competence is indeed determined by the Treaties, but it is subject to interpretation and resistance, and attempts are constantly being made to push its boundaries and to find new ways of framing issues so that they fall within, or outside, the EU's competence. In the case of the EU's agenda, competence is a major site of contestation. The competence argument needs to be constantly restated and it has to resist challenges made by the reframing of prostitution, as will be seen in the next section. The struggle around competence is active and a key factor in the politics of agenda setting. Examples of the work 
that needs to be done in order to frame and reframe an issue in relation to Treaty-based competence can be found in the 1996 Communication on trafficking in women for the purpose of sexual exploitation. For example: 'Trafficking in women appears to be largely in the hands of organised crime networks, operating as structured international enterprises. It may often be connected with other criminality, such as drugs trafficking. No single law enforcement agency in a Member State is able to combat trafficking alone.' (COM(96) 567 final, 1996, p. 15). This demonstrates that issues are not intrinsically within or outside the competence of the EU, but are framed in such a way that this can be claimed.

Finding 2 Framing plays an important part in silencing and in attempts to break the silence. We find efforts to frame prostitution in such a way that it falls within the EU's competence and efforts to frame it in such a way that it falls outside the EU's competence. The persistence of the use of the competence argument to keep prostitution off the EU agenda depends on a particular framing of prostitution. And this framing is often implicit, rather than explicit, constituted through silencing and through negative definition of what it is not. When prostitution is linked to sexual exploitation and trafficking in human beings, it falls within the competence of the EU. Otherwise, it is for the member states to decide which policy approaches to adopt. This ignores the ruling of the Court of Justice in Jany et al (Court of Justice of the European Union, 2001) that when prostitution is exercised in a self-employed capacity, it can be regarded as a service provided for remuneration and falls within the concept of 'economic activities'. So, this is a battle about issue definition in order to achieve agenda status, or to obstruct access to the agenda. Challenging the competence argument requires prostitution to be framed in such a way that it does fit within the competence of the EU. A strategy adopted by actors attempting to achieve this is to link prostitution with an issue which is already on the EU agenda, such as trafficking.

Linking prostitution to trafficking. Trafficking is on the agenda and is non-contentious. The successful linking of prostitution to trafficking would therefore bring it into the EU's competence, and this is one of the areas where the battle takes place. Activists, including feminists, are split around the question of what exactly the problem is and, following on from this, what solutions should be advocated (Davidson, 2002; Gangoli \& Westmarland, 2006a; Mathieu, 2003; V. Munro \& Della Giusta, 2008; Outshoorn, 2005). Those who believe that prostitution is an inherent form of violence and a violation of human dignity will seek the eradication of both prostitution and trafficking. Those who believe that what is wrong with prostitution is when it is exercised in conditions of exploitation, force, or coercion will seek the eradication of trafficking and forced prostitution, but not prostitution or sex work. The latter group will seek to separate prostitution and trafficking as policy issues, whereas the former will try to connect them. If the link can be made between prostitution and trafficking, then prostitution will achieve agenda status. Preventing this link requires a distinction to be maintained between forced and voluntary prostitution, where voluntary prostitution remains a matter for member states or is recognised as a form of service provision within the EU.

European Parliament resolution of 26 November 2009 on the elimination of violence against women (European Parliament, 2009) states that 'the tolerance of prostitution in Europe leads to an increase in trafficking of women into Europe for sexual purposes, and to sex tourism.' The argument that prostitution fuels trafficking makes the link between the two and justifies a call for policy action on prostitution. Mary Honeyball, UK MEP and author of the European Parliament report on sexual exploitation and prostitution which led to the 2014 Resolution, repeats this claim in her report to the European Parliament in 2014, arguing that reducing demand through client criminalisation would reduce trafficking. In response, however, a 
minority opinion by Angelika Niebler, Christa Klass, Astrid Lulling (Niebler, Klass, \& Lulling, 2014), argued that 'a distinction needs to be drawn between forced prostitution and legal prostitution, as provided for in Community legislation.' This would leave voluntary prostitution outside the competence of the EU and in the hands of each member state. In contrast, forced prostitution and human trafficking pose a cross-border problem that cannot be solved by any Member State acting alone. Member States must, they argue, cooperate closely to combat forced prostitution, human trafficking and organised crime.

There have been other advocates of this position in the European Parliament, as Outshoorn (2018) recalls. In the 1990s, prostitution was kept off the agenda by the explicit framing of trafficking and forced prostitution by actors such as Patsy Sorensen, a long-time activist against trafficking and forced prostitution from Antwerp, and an MEP for the Greens/European Left Alliance until 2004. Sorensen prepared the report for the FEMM committee on the European Communication on fighting trafficking, stressing that the issue was trafficking, and it should not be abused to provoke a debate about prostitution.

Linking prostitution to the sexual exploitation of children. The written question to the Commission by Andre Brie (GUE/NGL) (Brie, 2000) is one of many examples of where focus is centred on trafficking for sexual exploitation and child prostitution and pornography. The answer focuses on child sex tourism and child prostitution (whereas the question referred more generally to sex tourism, child prostitution and trafficking in human beings). Framing the problem in this way confines it to those issues which are non-contentious, and excludes discussions about prostitution. When they emerge, they are quashed with the competence argument. This is an example of controlling the scope of the policy debate, and has the effect of keeping prostitution off the agenda.

Linking prostitution to work, economic activity and the provision of services. The Court of Justice of the European Communities has made three rulings relevant to this framing (Court of Justice of the European Communities, 1982, 2001, 2015). In Jany and Others (Court of Justice of the European Communities, 2001), it ruled that, when undertaken in a self-employed capacity, prostitution is a service and therefore falls under the scope of provisions of Community legislation on the freedom to provide services. The case was brought by two Polish nationals and four Czech nationals, who were all working as window prostitutes in Amsterdam. They had been refused residence permits to enable them to work as prostitutes in a selfemployed capacity, on the ground that prostitution is a prohibited activity or at least not a socially acceptable form of work and cannot be regarded as being either a regular job or a profession. The ruling was about the Association Agreement between the Communities and Poland and the Czech Republic, which included the movement of workers. The Court ruled that prostitution pursued in a self-employed capacity can be regarded as a service provided for remuneration and falls within the concept of 'economic activities' (paragraph 49). The referring court had also raised the question of immorality. The Court ruled that 'Conduct which a Member State accepts on the part of its own nationals cannot be regarded as constituting a genuine threat to public order within the context of the Association Agreement' (paragraph 61). A derogation would only be applicable if the State had adopted effective measures to monitor and repress activities of that kind when they are also pursued by its own nationals.

Despite the ruling, this frame appears very rarely in EU documents. Activists and groups representing sex workers' rights are excluded from agenda setting and issue definition. The agenda setting literature suggests that linking prostitution to economic activity would be the 
most likely way for it to find a place on the EU agenda. That this obvious - if contentious frame is absent from the debates suggests systemic silencing.

Prostitution as a consequence of economic crisis/poverty/social inequality. The link between poverty and prostitution occurs mainly in reports by the European Economic and Social Committee (EESC), an EU advisory body comprising representatives of workers' and employers' organisations and other interest groups, which issues opinions to the European Commission, the Council of the EU and the European Parliament. On the rare occasions when the European Parliament mentions prostitution as a consequence of the economic crisis, it is as an example of one of the forms of violence against women which have increased, rather than as a product of economic constraint (European Parliament, 2013). One exception is the mention in Mary Honeyball's Report of 'the impact of the economic downturn on the growing number of women and under-age females, including migrant women, forced to enter prostitution' (Honeyball, 2014, para. 47). The report 'urges [the national] authorities to help them find alternative ways of earning a living and to support a safe environment for those who continue to work as prostitutes' and points out that 'economic problems and poverty are major causes of prostitution among young women and under-age females' (paragraph 48). She 'calls on the Member States to tackle the underlying social problems that force men, women and children into prostitution' (paragraph 49). There is complete silence in this and other European Parliament Resolutions on prostitution as an economic activity or as a form of work.

Linking prostitution to gender equality. This should be a successful way of linking prostitution to EU action, since the EU has a Treaty-based commitment to achieve gender equality in all areas of its activities. However, in practice, active efforts to achieve gender equality have been limited to employment and have more recently been diluted by the need to pay attention to multiple forms of discrimination and crosscutting issues, with no increase in resources. Examples of this framing can be found in Mary Honeyball's Report on Sexual Exploitation and Prostitution and its Impact on Gender Equality (Honeyball, 2014), followed by the European Parliament Resolution passed on 26 February 2014 (European Parliament, 2014), which links prostitution with gender equality in order to argue that it falls within the EU's remit. Honeyball states that prostitution is both a cause and a consequence of gender inequality. Framing it in this way, she argues that it falls within the EU's remit, since 'the Commission, in its Strategy for Equality Between Women and Men (2010-15) declares that "inequalities between women and men violate fundamental rights." Prostitution is "contrary to the principles of the Charter of Fundamental Rights of the European Union, including the goal and the principle of gender equality' (Honeyball, 2014). As we will see in the section on variations between different institutions, this frame has not gained traction outside the European Parliament.

Linking prostitution to violence against women. This has not proven very successful in terms of engaging EU policymaking, since only the European Parliament has been interested in violence against women (D'Ancona, 1984; European Parliament, 1986, 1989, 2003, 2011, 2014). Honeyball frames prostitution as a form of violence towards women and as both a cause and a consequence of gender inequality. The Daphne programme has provided funding to violence against women projects, some of which reach out to sex workers, but no hard policy on violence against women has been adopted. The frames which are present are the soft ones, which do not stand much of a chance of resulting in hard policy: gender equality and violence against women, both areas to which the EU pays lip service, which the European Parliament is particularly attached to, but which have not gone beyond general statements of principle (Allwood, Guerrina, \& MacRae, 2013; MacRae, 2010; Woodward \& van der Vleuten, 2014) 
The exception is trafficking in human beings, an issue on which the EU has produced hard policy in the form of the Anti-trafficking Directive (European Parliament \& The Council, 2011), along with the Strategy (European Commission, 2012) and the post of Anti-Trafficking Coordinator. If prostitution can be framed as linked to trafficking in human beings, then the chances of it achieving agenda status increase.

\section{Finding 3 There are differences between the EU institutions in the extent to which prostitution is present on, or absent from, the agenda and the ways in which it is framed.}

Different EU institutions have different agendas, and the power relations between them mean that the agendas of some institutions are more directly linked to the decision agenda that others. The Court of Justice has made three judgements relevant to prostitution (Court of Justice of the European Communities, 1982, 2001, 2015), all of which hinged on discrimination against nonnational workers, but this has not put prostitution on the broader EU agenda. The Commission and Council have framed prostitution as a matter for member states, leaving it undefined, but distinct from trafficking in human beings and, more recently, sexual exploitation (See for example Tomašić, 2014; Zuber et al., 2013).

The European Parliament regularly discusses prostitution, and the Commission and Council do not. Prostitution has been on the agenda of the European Parliament since 1984, most frequently in association with violence against women, but the other institutions have not reacted. In 1984, MEP Hedy d'Ancona produced a report on violence against women (D’Ancona, 1984) which resulted in the 1986 European Parliament Resolution on Violence against Women (European Parliament, 1986). It contained a section on prostitution which 'Calls attention to the hypocrisy of those societies which condemn and penalize prostitutes, while their 'clients', who are ultimately responsible for the prevalence of this phenomenon, have neither slur, nor stigma, nor prosecution to fear; $[\ldots]$ calls on the national authorities in the Member States to take the necessary legal steps: (a) to decriminalize the exercise of this profession, (b) to guarantee prostitutes the rights enjoyed by other citizens, (c)-to protect the independence, health and safety of those exercising this profession, (d) to reinforce measures which may be taken against those responsible for duress or violence to prostitutes, notably those forcing women to practise prostitution for their own financial gain, (e) to support prostitutes' self-help groups and to require police and judicial authorities to provide better protection for prostitutes who wish to lodge complaints against pimps in order to reduce their fear of being threatened by them.' Despite its successful adoption by the European Parliament, however, this Resolution was ignored by the Commission and the Council of Ministers, as has been the case for subsequent Resolutions. The European Parliament's position on prostitution has changed, with earlier texts calling for decriminalisation (European Parliament, 1986) 'respecting prostitutes and preventing discrimination against them or their further marginalisation or stigmatisation' (European Parliament, 2006); and the 2014 Resolution calling for a ban on the purchase of sexual services, without criminalising or penalising prostituted persons, and developing programmes 'to assist prostituted persons/sex workers to leave the profession should they wish to do so' (European Parliament, 2014, para. 30). The Honeyball Report (Honeyball, 2014, para. 37): 'Believes that looking upon prostitution as legal 'sex work', decriminalising the sex industry in general and making procuring legal is not a solution to keeping vulnerable women and under-age females safe from violence and exploitation, but has the opposite effect and puts them in danger of a higher level of violence, while at the same time encouraging prostitution markets - and thus the number of women and under-age females suffering abuse - to grow'. The unequal influence of the different EU 
institutions on the decision agenda means that the European Parliament and the Court's attention to prostitution has not resulted in EU agenda status.

Finding 4. Sex workers' rights advocates are excluded from decision-making and debates, and their discourse is silenced.

The absence or marginalisation of sex workers' rights advocates and sex work discourse shows their exclusion from agenda-setting processes. 'Sex work' appeared only nine times in all of the documents in EUR-Lex (1980-2016). This does not reflect the place of this discourse in European prostitution politics and debates (Gangoli \& Westmarland, 2006b; Grundell, 2015; V. E. Munro, 2006; Outshoorn, 2004). Institutional resistance takes place through selective access to decision making. Lucrecia Rubio Grundell (Grundell, 2015) argues that, although sex workers' civil society organisations are not formally excluded, they receive no direct EU funding; abolitionist tendencies exclude them from informal decision making; suspicions regarding their funding exist; and the interests they defend are not considered general.

Sex workers' rights' advocates responded to Mary Honeyball's report, stating that 'the criminalisation of sex workers and/or their clients will only increase the vulnerability of sex workers and will not lead to a decline in sex work nor a reduction in levels of violence against sex workers.' They called 'for the diverse experiences and voices of sex workers to be central to any changes in policy and law and demand the full and equitable rights of all sex workers, including to health and safety, in the European Union and beyond' (International Committee on the Rights of Sex Workers in Europe, 2014). A group of 94 academics signed a letter highlighting the 'inadequacies of the Report', criticising its sources, and its exclusion of sex workers and of academic publications demonstrating the problems associated with the model proposed. The exclusion of sex workers' rights advocates could be expected to contribute to the successful placing of prostitution on the EU agenda by the abolitionist lobby, which is gaining momentum. So far, however, resistance by individual and institutional actors has prevented them from achieving their goal.

\section{Conclusion}

This research found that the most common reason put forward for the exclusion of prostitution from the EU policy agenda is that it falls outside the competence of the EU. I argue, however, that competence does not explain prostitution's absence from the EU agenda. Instead, competence is used to justify the silencing of the issue. Competence is not fixed, but is subject to interpretation and resistance, and attempts are constantly being made to push its boundaries and to find new ways of framing issues so that they fall within, or outside, the EU's competence. In the case of the EU's agenda, competence is a major site of contestation. The competence argument needs to be constantly restated and it has to resist challenges made by the reframing of prostitution. The evidence presented here shows that absence from the agenda is not passive or accidental. Instead, the process of silencing the issue is active and institutionalised, in that it is restated regularly using the same discursive strategies. The institutionalisation of the competence argument as a way of keeping prostitution off the agenda illustrates the constant shoring up of the status quo and the balance of power in favour of the agenda setters, confirming Freedman's (2010) argument in his work on media silences. Attempts to reframe the issue in such a way that it falls within the competence of the EU are quashed with the competence argument. These include efforts to frame prostitution as an issue of employment, free movement, or gender equality, any of which would link it to EU concerns. The struggle around competence is active and a key factor in the politics of EU agenda setting. 
The research confirms the literature which highlights the importance of framing both in silencing and in attempts to break the silence (Birkland, 2007; Freedman, 2010; Princen, 2011b). The findings show that there have been attempts to place prostitution on the agenda, and that different actors have framed the issue in different ways. Similarly, actors have used different framing strategies to block these attempts. They have framed it as an issue which falls within the competence of member states, and focused solely on trafficking in human beings or child prostitution and pornography, maintaining silence on prostitution framed as work, violence or a consequence of gender and other inequalities. Those who are attempting to preserve the status quo have rebutted, ignored or twisted the frames presented by advocates for policy change. Rebuttal is the rarest of these strategies. There are few direct conflicts in EU policy debates over whether prostitution is a form of work or violence, for example. Instead, claims for prostitution's inclusion on the agenda on the grounds that it is a form of sex work are ignored outside the Court, and claims for inclusion on the grounds that it is a form of violence are ignored outside the Parliament. The Commission either silences these claims with the competence argument or twists the frame to encompass more consensual issues, such as trafficking, or child pornography and prostitution.

In contrast to trafficking, prostitution does not unite an advocacy coalition, presenting a single framing of the issue and proposing a single solution. Instead, there are deep divisions between those who advocate the eradication of prostitution on the grounds that it is an inherent act of violence against women and a violation of human dignity and, on the other hand, those who oppose trafficking and forced prostitution, but advocate the protection of sex workers' rights. Member states are divided, with the Nordic countries and France supporting the former position, and Austria, Belgium and the Netherlands supporting the latter (Outshoorn 2018). Civil society organisations are also divided. The European Women's Lobby has taken a strong abolitionist stance since 1998, later calling on its member organisations to lobby their national governments to criminalise clients, but there are fierce criticisms of its position by sex workers' rights', human rights, and feminist organisations, including the International Committee on the Rights of Sex Workers in Europe, Amnesty International and the Association for Women in Development.

Linking prostitution to gender equality should be a successful way of linking prostitution to EU action, since the EU has a Treaty-based commitment to achieve gender equality in all areas of its activities. However, the wider EU policy environment is one in which gender equality is slipping down the agenda in a time of multiple crises (Allwood et al., 2013; Emejulu \& Bassel, 2015; Kantola \& Lombardo, 2017; Weiner, 2014). Despite the EU's frequently declared commitment to gender equality as one of its fundamental values, gender issues are still seen as add-ons, minority concerns, and certainly not political priorities (Allwood, 2015). If the silence is broken and prostitution does arrive on the EU policy agenda, it will be as a result of expanding the scope of the EU's gender policy. At the moment, the scope of the EU's gender policy is, on the contrary, shrinking (Kantola \& Lombardo, 2017; Weiner, 2014).

This article has demonstrated that it is possible for an issue to be on the agenda of one or more EU institutions, whether this is the Committee on Gender Equality (FEMM) in the European Parliament or the European Parliament as a whole, without it reaching the decision making stage. This confirms Princen (2012, p. 29), who shows that agenda setting in the EU is rendered particularly complex by the number and interrelation of institutions, and that there are numerous points where issues can be blocked. The formal institutions of the EU provide both opportunities and obstacles for those seeking to bring a new issue to the agenda. In this case, we see that actors framing prostitution as a form of work have used the courts to achieve certain 
decisions and definitions. However, this has not spread to the other institutions. Actors framing prostitution as a form of violence have targeted the EP, and in particular its women's rights committee, and have succeeded in passing a Resolution, but this is non-binding. The Commission and the Council have ignored the issue. The Court of Justice has made three judgements relevant to prostitution (Court of Justice of the European Communities, 1982, 2001, 2015), all of which hinged on discrimination against non-national workers, but this has not put prostitution on the broader EU agenda. The Commission and Council have framed prostitution as a matter for member states, leaving it undefined, but distinct from trafficking in human beings and, more recently, sexual exploitation. The European Parliament regularly discusses prostitution, and the Commission and Council do not. The relative balance of power between the institutions means that unless an issue is on the agenda of the Council and Commission, it will not lead to EU decision making.

This article makes two distinct theoretical contributions: it explains why issues are marginalised in EU institutions; and it explains why prostitution is not considered an issue for EU decision-making. It also makes an empirical contribution in that it shows how this active exclusion and silencing takes place. Institutional resistance takes place through selective access to decision making, confirming the findings of existing scholarship (Annesley \& Gains, 2013; Gains \& Lowndes, 2015). Institutional resistance, taking the form of incredulity or incomprehension in the face of claims that the EU is bound to act on gendered issues, supported by the competence argument, has made it very difficult for advocates to gain a foothold. Sex workers' rights advocates can see successful rulings by the Court, but are otherwise silenced and excluded. Abolitionists are in a stronger position, dominating the single women's rights umbrella organisation, the European Women's Lobby, and led by vocal and active campaigners in the European Parliament. But still they have failed to secure recognition of prostitution as an EU policy issue by the Commission and the Council. Calls for action on prostitution are not engaged with or argued over. They are ignored or silenced with the competence argument. This study reveals the power of policy silence. It finds an active process of silencing, reliant on the argument that prostitution falls outside the competence of the EU, combined with the twisting of questions about prostitution to focus solely on the more consensual issues of child prostitution and pornography and trafficking in human beings. Prostitution, whether it is framed as a form of violence, a cause or consequence of gender inequality, or a form of work, does not have a place on the EU's decision agenda.

\section{References}

Allwood, G. (2015). Horizontal policy coordination and gender mainstreaming: The case of the European Union's Global Approach to Migration and Mobility. Women's Studies International Forum, 48. https://doi.org/10.1016/j.wsif.2014.10.004

Allwood, G., Guerrina, R., \& MacRae, H. (2013). Unintended consequences of EU policies: Reintegrating gender in European studies. Women's Studies International Forum, 39. https://doi.org/10.1016/j.wsif.2013.05.001

Annesley, C., Engeli, I., \& Gains, F. (2015). The Profile of Gender Equality Issue Attention in Western Europe. European Journal of Political Research, 54, 525-542.

Annesley, C., \& Gains, F. (2013). Investigating the Economic Determinants of the UK Gender Equality Policy Agenda. British Journal of Politics and International Relations, 15, 125146.

Askola, H. (2007). Violence against Women, Trafficking, and Migration in the European Union. European Law Journal, 13(2), 204-217. https://oi.org/10.1111/j.14680386.2007.00364.x 
Birkland, T. A. (2007). Agenda setting in public policy. In and M. S. S. Fischer, Frank, Gerald Miller (Ed.), Handbook of Public Policy Analysis: Theory, Politics, and Methods. (pp. 63-78). Boca Raton: CRC/Taylor \& Francis.

Brie, A. (2000). Written Question E-2562/00 by Andre Brie (GUE/NGL) to the Commission (28 July 2000) Subject: Sex tourism and child prostitution at the EU's external border with the Czech Republic. European Parliament.

Buonanno, L., \& Nugent, N. (2013). Policies and Policy Processes of the European Union. Basingstoke: Palgrave Macmillan.

Candel, J. J. L., Breeman, G. E., \& Termeer, C. J. A. M. (2016). The European Commission's ability to deal with wicked problems: an in-depth case study of the governance of food security. Journal of European Public Policy, 23(6), 789-813. https://doi.org/10.1080/13501763.2015.1068836

COM(96) 567 final. Communication From The Commission To The Council And The European Parliament On Trafficking In Women For The Purpose Of Sexual Exploitation Brussels, 20.11.1996 COM(96) 567 final (1996).

Court of Justice of the European Communities. (1982). Joined cases 115 and 116/81 Adoui and Cornuaille [1982] ECR 1665, ECLI:EU:C:1982:183.

Court of Justice of the European Communities. (2001). Jany and Others Case C-268/99 ECLI:EU:C:200:616.

Court of Justice of the European Communities. (2015). Joined Cases C 340/14 and C 341/14 Trijber and Harmsen ECLI:EU:C:2015:641;

Court of Justice of the European Union. (2001). Judgment of the Court of 20 November 2001. Aldona Malgorzata Jany and Others $v$ Staatssecretaris van Justitie. Reference for a preliminary ruling: Arrondissementsrechtbank te 's-Gravenhage - Netherlands. External relations - Association agreements between.

D'Ancona, H. (1984). Report to the European Parliament on Violence Against Women (Doc. A 2-44/86).

Davidson, J. O. (2002). The Rights and Wrongs of Prostitution. Hypatia, 17(2), 84-98.

Dury, M. (1989). Written Question No 2202/88 by Mrs Dury (S-B) to the Commission of the European Communities (14 February 1989) (89/C 180/95). Subject: United Nations Convention of 2 December 1949.

Elman, R. A. (2007). Sexual Equality in an Integrated Europe: Virtual Equality. Basingstoke: Palgrave.

Emejulu, A., \& Bassel, L. (2015). Minority women, austerity and activism. Race \& Class, 57(2), 86-95. https://doi.org/10.1177/0306396815595913

European Commission. (2012). EU Strategy Towards the Eradication of Trafficking in Human Beings 2012-2016 COM(2012)286 final.

European Parliament. (1986). Resolution on Violence against Women, Doc. A2-44/86, OJ. C. 176, 14 July 86, p. 73-83.

European Parliament. (1989). Resolution on the exploitation of prostitution and the traffic of human beings, OJ C 120, 16.5.1989, p. 352.

European Parliament. (2003). Resolution on the situation of women from minority groups in the European Union (2003/2109(INI)).

European Parliament. Recommendation to the Council on fighting trafficking in human beings - an integrated approach and proposals for an action plan (2006/2078(INI)) (2006).

European Parliament. (2009). Resolution of 26 November 2009 on the elimination of violence against women. Retrieved from http://eur-lex.europa.eu/legalcontent/EN/TXT/?uri=CELEX\%3A52009IP0098(01)

European Parliament. (2011). Resolution of 5 April 2011 on priorities and outline of a new EU policy framework to fight violence against women, 2010/2209(INI). 
European Parliament. (2013). Report on the Impact of the Economic Crisis on Gender Equality and Women's Rights 2012/2301(INI), 28 February.

European Parliament. (2014). Resolution of 26 February 2014 on sexual exploitation and prostitution and its impact on gender equality (2013/2103(INI)).

European Parliament, \& The Council. (2011). Directive 2011/36/EU of the European Parliament and of the Council of 5 April 2011 on preventing and combating trafficking in human beings and protecting its victims, and replacing Council Framework Decision 2002/629/JHA.

Freedman, D. (2010). Media Policy Silences: The Hidden Face of Communications Decision Making. The International Journal of Press/Politics, 15.

Gains, F., \& Lowndes, V. (2015). Making Violence Against Women a Political Priority. The Importance of Sub-National Institutions in Shaping Gender Policy Reform: a Case Study of the New Police and Crime Commissioners in England and Wales. Working Papers in Gender and Institutional Change, (3).

Gangoli, G., \& Westmarland, N. (2006a). International Approaches to Prostitution: Law and Policy in Europe and Asia. Bristol: Policy Press.

Gangoli, G., \& Westmarland, N. (Eds.). (2006b). International approaches to prostitution Law and policy in Europe and Asia. Bristol: Policy Press.

Grundell, L. R. (2015). Sex Workers' Organisations and EU Policy-Making: Explaining an Institutional and Ideational Exclusion. Draft paper ECPR 11-13 June 2015, Uppsala.

Honeyball, M. (2014). Report on Sexual Exploitation and Prostitution and its Impact on Gender Equality. Retrieved from http://www.europarl.europa.eu/sides/getDoc.do?pubRef=-//EP//TEXT+REPORT+A72014-0071+0+DOC+XML+V0//EN\#top

Hoskyns, C. (1996). Integrating Gender: Women, Law and Politics in the EU. London and New York: Verso.

International Committee on the Rights of Sex Workers in Europe. (2014). Press Release: 560 NGOs and 94 Researchers Demand Members of European Parliament to Reject Ms Honeyball's Report. Retrieved from http:/www.sexworkeurope.org/news/generalnews/560-ngos-and-94-researchers-demand-members-european-parliament-reject-mshoneyball

Joachim, J. (2007). Agenda Setting, the UN and NGOs: Gender Violence and Reproductive Rights. Washington DC: Georgetown University Press.

Kantola, J., \& Lombardo, E. (Eds.). (2017). Gender and the Economic Crisis in Europe: Politics, Institutions and Intersectionality. Basingstoke: Palgrave Macmillan.

Kenney, S. J. (2003). Where is gender in agenda setting? Women \& Politics, 25(1-2), 179207.

Kenny, M., \& Mackay, F. (2009). Already Doin' It for Ourselves? Skeptical Notes on Feminism and Institutionalism. Politics and Gender, 5(2), 271-280.

Kronsell, A. (2012). Gendering Theories of European Integration. In G. Abels \& J. M. Mushaben (Eds.) (pp. 23-40). Basingstoke: Palgrave.

Lobby, E. W. (2013). The Brussels Call. Together for a Europe Free From Prostitution. Retrieved from http://www.womenlobby.org/-the-brussels-call-together-for-a-?lang=en

Locher, B. (2007). Trafficking in Women in the European Union Norms, Advocacy-Networks and Policy-Change. Wiesbaden: Springer VS.

Locher, B. (2012). Gendering the EU Policy Process and Constructing the Gender Acquis; In G. Abels \& J. M. Mushaben (Eds.).

Lovenduski, J. (1986). Women and European Politics: Contemporary Feminism and Public Policy. University of Massachusetts Press.

Mackay, F. (2011). Towards a Feminist Institutionalism. In M. L. Krook \& F. Mackay (Eds.) 
(pp. 181-196).

Mackay, F., \& Waylen, G. (2009). Critical Perspectives on Gender and Politics: Feminist Institutionalism. Politics and Gender, 5, 237-280.

MacRae, H. (2010). The EU as a Gender Equality Polity: Myths and Realities. Journal of Common Market Studies, 48(1), 153-172.

Mathieu, L. (2003). The Emergence and Uncertain Outcomes of Prostitutes' Social Movements. European Journal of Women's Studies, 10(1).

Mergaert, L., \& Lombardo, E. (2017). Resistance to Implementing Gender Mainstreaming in EU Research Policy. In H. MacRae \& E. Weiner (Eds.), Towards Gendering Institutionalism Equality in Europe (pp. 101-120). London and New York: Rowman and Littlefield.

Montoya, C. (2013). From Global to Grassroots: The European Union, Transnational Advocacy, and Combating Violence Against Women. Oxford: Oxford University Press.

Munro, V., \& Della Giusta, M. (2008). Demanding sex : critical reflections on the regulation of prostitution. Aldershot: Ashgate.

Munro, V. E. (2006). Stopping Traffic? A Comparative Study of Responses to the Trafficking in Women for Prostitution. British Journal of Criminology, 46(2), 318-333.

Niebler, A., Klass, C., \& Lulling, A. (2014). Minority Opinion on Motion for a European Parliament Resolution on Sexual Exploitation and Prostitution. Retrieved from http://www.europarl.europa.eu/sides/getDoc.do?pubRef=-//EP//TEXT+REPORT+A72014-0071+0+DOC+XML+V0//EN\#title3

Nugent, N. (2017). The Government and Politics of the European Union, 8th Edition (8th Editio). Basingstoke and New York: Palgrave Macmillan.

Outshoorn, J. (Ed.). (2004). The Politics of Prostitution: Women's Movements, Democratic States, and the Globalization of Sex Commerce. Cambridge: Cambridge University Press.

Outshoorn, J. (2005). The Political Debates on Prostitution and Trafficking of Women. Social Politics: International Studies in Gender, State \& Society, 12(1), 141-155.

Outshoorn, J. (2018). European Union and Prostitution Policy. In J. Økland \& H. Wagenaar (Eds.), Assessing Prostitution Policies in Europe. Abingdon: Routledge.

Princen, S. (2007). Agenda-setting in the European Union: a theoretical exploration and agenda for research. Journal of European Public Policy, 14(1), 21-38.

Princen, S. (2011a). Agenda-setting strategies in EU policy processes. JEPP, 18(7), 927--943.

Princen, S. (2011b). Agenda Setting. In E. Versluis, M. van Keulen, \& P. Stephenson (Eds.) (pp. 107-131).

Princen, S. (2012). “Agenda-setting and the formation of an EU Policy-making State.” In J. J. Richardson (Ed.) (pp. 30-46).

Princen, S. (2016). No Title. In N. Zahariadis (Ed.), Handbook of Public Policy Agenda Setting (pp. 348-366). Cheltenham: Edward Elgar.

Randall, V. (1987). Women and Politics (Second Edi). London: Macmillan.

Schön, D. A., \& Rein, M. (1994). Frame Reflection: Toward the Resolution of Intractable Policy Controversies. New York: Basic Books.

Tocci, N. (2016). The EU Global Strategy on foreign and security policy, Talk given at the 2016 Jean Monnet Conference on Global Governance in Times of Global Challenges, Brussels, 17-18 October.

Tomašić, R. (2014). Question for written answer E-003577/14 to the Commission Ruža Tomašić (ECR) (24 March 2014) Subject: Differentiated approach to combating prostitution on behalf of the Commission (19 May 2014).

van Dijk, N. (1989). Written Question No 817/89 by Mrs Nel van Dijk (V) to the Council of the European Communities (28 November 1989) (90/C 69/77). Subject: Decriminalization of prostitution. 
Waylen, G. (2014). Informal Institutions, Institutional Change, and Gender Equality. Political Research Quarterly.

Weiner, E. and H. M. (2014). The persistent invisibility of gender in EU policy: Introduction, Special issue. European Integration Online Papers (EIoP), 1(18), 1-20.

Weldon, L. (2002). Protest, Policy and the Problem of Violence Against Women. Pittsburgh: University of Pittsburgh Press.

Woodward, A., \& van der Vleuten, A. (2014). EU and the Export of Gender Equality Norms: Myth and Facts. In A. van der Vleuten, A. van Eerdewijk, \& C. Roggeband (Eds.) (pp. 67-92). Basingstoke: Palgrave Macmillan.

Zuber, I. C., Auconie, S., Honeyball, M., Kiil-Nielsen, N., \& Parvanova, A. (2013). Question for written answer E-006332/13 to the Commission Inês Cristina Zuber (GUE/NGL), Sophie Auconie (PPE), Mary Honeyball (S\&D), Nicole Kiil-Nielsen (Verts/ALE) and Antonyia Parvanova (ALDE) (4 June 2013). 